\title{
Wear of the Implant Connection with Zirconia and Titanium
}

\section{Abutments}

\section{José $\mathrm{AR}^{1 *}$, Marco $\mathrm{M}^{2}$, Maurício $\mathrm{PJ}^{1}$, Diogo $\mathrm{M}^{3}$, Fátima Vaz $\mathrm{M}^{4}$, Luís $\mathrm{R}^{4}$ and Ignacio $\mathrm{BN}^{5}$}

${ }^{1}$ Faculty of Oral Rehabilitation, Instituto Superior de Ciências da Saúde Egas Moniz, Portugal

2Universidade de Lisboa, Portugal

${ }^{3}$ Department of Design and Engineering, Bournemouth University, UK

${ }^{4}$ Departamento de Engenharia Mecânica, Universidade de Lisboa, Portugal

${ }^{5}$ Facultad de Odontología, Universidad de Sevilla, Spain

*Corresponding author: José Alexandre Reis, Faculty of Oral Rehabilitation, Instituto Superior de Ciências da Saúde Egas Moniz, Portugal, Tel: 00351214402047; E-mail: josealexandrereis@gmail.com; jreis@egasmoniz.edu.pt

\section{Abstract}

Background: Classify and quantify the wear of the implant and abutment interface simulating a loose screw situation.

Methods: Nine external connection titanium implants were split into 4 groups: Group A (no hexagon titanium abutment), Group B Titanium abutment (with hexagon) (n=3), Group C Zirconia abutment with hexagon (n=3) and Group D mix abutments $(n=2)$. All components were individually weighted and the rotational freedom for each pair was access before and after testing. The specimens were tested an Instron 8874 fitted with a dynamic load cell with a torque capacity of $100 \mathrm{Nm}$ and a precision of $0.5 \%$ from $1 \%$ of the full scale. They were loaded with a sinusoidal rotational angle that was different for each group $\left(A=6^{\circ}, B=3.3^{\circ}, C=0.835^{\circ}, D=6.6^{\circ}\right), 4 \mathrm{~Hz}$, for 250.000 cycles. After testing all components were photographed with a SEM. Spearman's correlation analysis was made.

Results: Regardless of angle and materials the rotational freedom increased in all groups. Volume loss with zirconia abutment was more than double than with a titanium abutment.

Conclusion: The loose screw in implant prosthesis may lead to the wear of the hexagon on both components. This wear is sufficient to compromise the connection beyond repair.

Keywords: Titanium abutment; Zirconia abutment; Loose screw

Abbreviations: SEM: Scanning Electron Microscopy; FEG: Field Emission Gun

\section{Introduction}

Single implant crown is a routine procedure worldwide. It is a simple predictable treatment supported by several studies [1,2]. In contrast to the high success rates of osseointegration (95\% to 97\%), mechanical complications are still common in implant dentistry $[3,4]$. Mechanical complications such as screw loosening, screw fracture, and framework fracture have been reported to 


\section{Open Access Journal of Dental Sciences}

be as high as $44.9 \%[4,5]$. Despite the existence of several different implant/abutment interfaces, the external hexagonal geometry remains the most common design in use [6]. The use of stabilized zirconium oxide $\left(\mathrm{ZrO}_{2}\right)$ as an aesthetic material has emerged as meeting the needs of most resistant prostheses [7]. The literature on the mechanical behaviour of zirconia samples is scarce, but some point out towards similar success rates for both zirconia and titanium abutments materials [8]. Fatigue tests studies have used different methodologies for the applied axial load, frequency, and number of cycles $[6,9,10]$. The frequency of cycles is reported in the literature as ranging from 1 to $19 \mathrm{~Hz}$ [10]. An individual typically performs three episodes of chewing lasting 15 min, with a frequency of 60 cycles per minute $(1 \mathrm{~Hz})$; this generates 2700 chewing cycles per day, which equals 1 million cycles per annum [9]. The connection between zirconia and the implant is a mechanical challenge. There is still sparse information regarding what happens in the hexagon implant-abutment connection. Implant components vary in accuracy, consistency, and fidelity due to the different machine tolerances in fabrication. Rotational freedom can be defined as the difference between the patrix implant hexagonal extension and the matrix hexagonal abutment counterpart [11] in a small mastication simulation test (only 500 cycles) found titanium debris abraded from the external hexagon by the aluminum oxide abutment (ZiReal Post) [11]. The goal of this work was to study the implant-abutment connection after shear/torsion scenario of repetitive loads which induce a loosening of the abutment that mimic the loose screw condition. To our best knowledge torsional tests were only conducted at the bone-implant interface [12].

\section{Materials}

Nine external connection titanium implants Lance $4 \times 10 \mathrm{~mm}$ (MIS Implants Technologies Ltd, Bar Lev Industrial Park, Israel) Lot W0198132, were embedded with acrylic resin Orthocryl (Dentautum GmbH Co. KG, Ispringen, Germany). The implant systems were split into 4 groups: Group A or control (no hexagon titanium abutment), Group B Titanium abutment (with hexagon) $(n=3)$, Group C Zirconia abutment with hexagon $(n=3)$ and Group D mix abutments ( $\mathrm{n}=2)$.

The Zirconia abutments (ICE Zirkon, Zirkonzahn GmbH, Gais, Italy) were custom made by an expert laboratory technician. Prior to testing, the rotational freedom for each pair was access with a custom made device as described by Binon (Binon PP. Evaluation of machining accuracy and consistency of selected implants, standard abutments, and laboratory analogs. All components were individually weight in a scale, FR-300 (A\&D, Tokyo, Japan) with a precision of 0,01 mg before and after testing. Each pair was torqued with a titanium screw (REF CO-S0240 Lot W02176744 MIS Implants Technologies Ltd, Bar Lev Industrial Park, Israel) to $35 \mathrm{~N} / \mathrm{cm}$ with a BTG60CN-S (TOHNICHI,Tokyo, Japan) torque wrench, as recommended by the manufacturer. The specimens were secured first on the lower grip of an Instron 8874 (Instron Corporation, Norwood, MA, USA) machine at 30 bar $\left(300 \mathrm{~N} / \mathrm{cm}^{2}\right)$. Increased care was taken to verify the verticality of the specimen. The upper grip of the testing machine was equipped with a dynamic load cell (biaxial 2527-111 Dynacell ${ }^{\text {TM }}$ (Instron Corporation, Norwood, MA, Estados Unidos)) with a torque capacity of $100 \mathrm{Nm}$ and a precision of $0.5 \%$ from $1 \%$ of the full scale. The specimens were loaded with a sinusoidal rotational angle, $\theta$ given in Table 1 at a frequency of $4 \mathrm{~Hz}$, for 250.000 cycles. A $100 \mathrm{~N}$ vertical compressive force was used to simulate occlusion and to help stabilize the apparatus. After testing the rotational freedom was measured, and the abutments were carefully disconnected and photographed. Scanning electron microscopy (SEM) analysis was carried out at MicroLab (Instituto Superior Técnico, Universidade de Lisboa, Portugal) on implants before and after the cyclic tests, to illustrate the damage caused by twisting. SEM analysis was carried out in a field emission gun scanning electron microscope FEG-SEM (model 7001 F, JEOL) using an accelerating voltage of $10 \mathrm{kV}$. During testing one of the specimens failed and was replaced by a new one. Statistical analysis was performed using the software SPSS (Statistics 22, 2016, IBM USA). The Spearman's correlation coefficients were applied to correlate the rotational freedom with the volume loss of the dental components. Correlations were statistically significant for $\mathrm{p}$-value lower than 0.05 , while for $\mathrm{p}$-value lower than 0.01 , they were highly statistically significant.

\begin{tabular}{|c|c|c|}
\hline & Number of specimens & Angle $\boldsymbol{\theta}$ (-) \\
\hline Group A & 1 & 6 \\
\hline Group B & 3 & 3,3 \\
\hline Group C & 3 & 0,835 \\
\hline Group D & 2 & 6,6 \\
\hline
\end{tabular}

Table 1: Sinusoidal rotational angle, $\theta$ assigned for each group.

\section{Results}

In all groups, after testing the screws were all loose. In group A the rotational freedom increased from 1,706 to 7,267 more than 4 times (Table 2). In Group B the increase was lower, only $1,7 \mathrm{x}$ more from $1,910^{\circ}$ to $3,291^{\circ}$ (Table 2). In Group $C$ the both the hexagons were completely destroyed as expected so it was impossible to measure a value. The volume loss was greater for all 
groups in the implant (Table 3). The Zirconia abutment suffered little wear but caused the most damage to the implant. In the Spearman's correlation analysis of all groups (Table 4), as expected, there is a negative correlation between the increase in rotational freedom and the wear of the abutment $(\mathrm{p}<0.05, \mathrm{r}=-0.640)$. There is a negative correlation between the test angle and the volume of implant $(\mathrm{p}<0.05, \mathrm{r}=-0.719)$ and abutment $(p<0.01, r=-0.947)$ material lost. There is a positive correlation between the volume of implant $(p<0.01$, $\mathrm{r}=0.802)$ and abutment $(\mathrm{p}<0.01, \mathrm{r}=0.976)$ material lost with the vertical movement. A positive correlation between the volume of implant and abutment material lost $(\mathrm{p}<0.01, r=0.863)$ was found. In the Spearman's correlation analysis of groups A and B (Table 5), there is a negative correlation between the increase in rotational freedom and the wear of the abutment $(\mathrm{p}<0.01, \mathrm{r}=$ 0.986). There is a positive correlation between the volume of abutment $(\mathrm{p}<0.05, \mathrm{r}=0.899)$ with the vertical movement. A positive correlation between the volume of implant and abutment material lost $(\mathrm{p}<0.01, \mathrm{r}=0.863)$ was found. Analyzing the Spearman's correlation data from the individual abutment types was not possible due to the small sample.

\begin{tabular}{|c|c|c|}
\hline & Before & After \\
\hline Group A & 360 & 360 \\
\hline Group B & $1,706^{\circ} \pm 0,187^{\circ}$ & $7,260^{\circ} \pm 3,305^{\circ}$ \\
\hline Group C & $1,910^{\circ} \pm 0,545^{\circ}$ & $3,291^{\circ} \pm 0.901^{\circ}$ \\
\hline
\end{tabular}

Table 2: Rotational Freedom.

\begin{tabular}{|c|c|c|}
\hline & Implant & Abutment \\
\hline Group A & 1,377 & 1,163 \\
\hline Group B & $1,708 \pm 1,200$ & $1,459 \pm 0,729$ \\
\hline Group C & $1,399 \pm 0,021$ & $0,021 \pm 0,013$ \\
\hline $\begin{array}{c}\text { Group D - } \\
\text { Titanium }\end{array}$ & 2,753 & 2,934 \\
\hline $\begin{array}{c}\text { Group D - } \\
\text { Zirconia }\end{array}$ & 6,185 & 0,081 \\
\hline
\end{tabular}

Table 3: Volume loss in grams $/ \mathrm{mm}^{3}$.

\begin{tabular}{|c|c|c|c|c|c|c|c|c|c|}
\hline & & $\begin{array}{c}\text { Test } \\
\text { Angle }\end{array}$ & $\begin{array}{c}\text { Initial } \\
\text { Rotational } \\
\text { Freedom }\end{array}$ & $\begin{array}{c}\text { Final } \\
\text { Rotational } \\
\text { Freedom }\end{array}$ & $\begin{array}{l}\text { Rotationa } \\
\text { Freedom } \\
\text { Increase }\end{array}$ & \begin{tabular}{|c|} 
Implant \\
Volume \\
Loss \\
(mm3)
\end{tabular} & $\begin{array}{l}\text { Abutment } \\
\text { Volume } \\
\text { Loss } \\
\text { (mm3) } \\
\end{array}$ & $\begin{array}{l}\text { Max Torque } \\
\text { Clockwise }\end{array}$ & $\begin{array}{l}\text { Max Torque } \\
\text { Counter } \\
\text { Clockwise }\end{array}$ \\
\hline \multirow[t]{2}{*}{ Test Angle } & $\begin{array}{c}\text { Correlation } \\
\text { Coefficient }\end{array}$ & & $-0,293$ & ,878* & ,878* & $-0,098$ &,$- 891 *$ & $-0,293$ & $-0,683$ \\
\hline & Sig. (2-tailed) & & 0,573 & 0,021 & 0,021 & 0,854 & 0,017 & 0,573 & 0,135 \\
\hline \multirow{2}{*}{$\begin{array}{l}\text { Initial Rotational } \\
\text { Freedom }\end{array}$} & $\begin{array}{c}\text { Correlation } \\
\text { Coefficient }\end{array}$ & $-0,293$ & & $-0,143$ & $-0,143$ & $-0,429$ & 0,029 & 0,086 & 0,200 \\
\hline & Sig. (2-tailed) & 0,573 & & 0,787 & 0,787 & 0,397 & 0,957 & 0,872 & 0,704 \\
\hline \multirow{2}{*}{$\begin{array}{l}\text { Final Rotational } \\
\text { Freedom }\end{array}$} & $\begin{array}{c}\text { Correlation } \\
\text { Coefficient }\end{array}$ & ,878* & $-0,143$ & & $1,000^{* *}$ & $-0,543$ &,$- 986^{* *}$ & $-0,429$ & $-0,314$ \\
\hline & Sig. (2-tailed) & 0,021 & 0,787 & & 0,000 & 0,266 & 0,000 & 0,397 & 0,544 \\
\hline \multirow{2}{*}{$\begin{array}{c}\text { Rotational Freedom } \\
\text { Increase }\end{array}$} & $\begin{array}{l}\text { Correlation } \\
\text { Coefficient }\end{array}$ & ,878* & $-0,143$ & $1,000^{* *}$ & & $-0,543$ &,$- 986^{* *}$ & $-0,429$ & $-0,314$ \\
\hline & Sig. (2-tailed) & 0,021 & 0,787 & 0,000 & & 0,266 & 0,000 & 0,397 & 0,544 \\
\hline \multirow{2}{*}{$\begin{array}{l}\text { Implant Volume Loss } \\
\text { (mm3) }\end{array}$} & $\begin{array}{l}\text { Correlation } \\
\text { Coefficient }\end{array}$ & $-0,098$ & $-0,429$ & $-0,543$ & $-0,543$ & & 0,522 & 0,257 & $-0,486$ \\
\hline & Sig. (2-tailed) & 0,854 & 0,397 & 0,266 & 0,266 & & 0,288 & 0,623 & 0,329 \\
\hline \multirow{2}{*}{$\begin{array}{l}\text { Abutment Volume } \\
\text { Loss (mm3) }\end{array}$} & $\begin{array}{c}\text { Correlation } \\
\text { Coefficient }\end{array}$ &,$- 891^{*}$ & 0,029 &,$- 986^{* *}$ &,$- 986^{* *}$ & 0,522 & & 0,406 & 0,406 \\
\hline & Sig. (2-tailed) & 0,017 & 0,957 & 0,000 & 0,000 & 0,288 & & 0,425 & 0,425 \\
\hline \multirow{2}{*}{$\begin{array}{l}\text { Max Torque } \\
\text { Clockwise }\end{array}$} & $\begin{array}{l}\text { Correlation } \\
\text { Coefficient }\end{array}$ & $-0,293$ & 0,086 & $-0,429$ & $-0,429$ & 0,257 & 0,406 & & $-0,086$ \\
\hline & Sig. (2-tailed) & 0,573 & 0,872 & 0,397 & 0,397 & 0,623 & 0,425 & & 0,872 \\
\hline \multirow{2}{*}{$\begin{array}{c}\text { Max Torque Counter } \\
\text { Clockwise }\end{array}$} & $\begin{array}{l}\text { Correlation } \\
\text { Coefficient }\end{array}$ & $-0,683$ & 0,200 & $-0,314$ & $-0,314$ & $-0,486$ & 0,406 & $-0,086$ & \\
\hline & Sig. (2-tailed) & 0,135 & 0,704 & 0,544 & 0,544 & 0,329 & 0,425 & 0,872 & \\
\hline
\end{tabular}

*. Correlation is significant at the 0.05 level (2-tailed)

**. Correlation is significant at the 0.01 level (2-tailed)

Table 4: Spearman's correlation analysis all groups. 


\section{Open Access Journal of Dental Sciences}

\begin{tabular}{|c|c|c|c|c|c|c|c|c|c|}
\hline & & $\begin{array}{c}\text { Test } \\
\text { Angle }\end{array}$ & \begin{tabular}{|c|} 
Initial \\
Rotational \\
Freedom
\end{tabular} & $\begin{array}{c}\text { Final } \\
\text { Rotational } \\
\text { Freedom }\end{array}$ & \begin{tabular}{|c} 
Rotational \\
Freedom \\
Increase
\end{tabular} & \begin{tabular}{|c|} 
Implant \\
Volume \\
Loss \\
$(\mathrm{mm} 3)$
\end{tabular} & \begin{tabular}{|c|} 
Abutment \\
Volume \\
Loss \\
(mm3) \\
\end{tabular} & $\begin{array}{c}\text { Max } \\
\text { Torque } \\
\text { Clockwise }\end{array}$ & $\begin{array}{l}\text { Max Torque } \\
\text { Counter } \\
\text { Clockwise }\end{array}$ \\
\hline & $\begin{array}{c}\text { Correlation } \\
\text { Coefficient }\end{array}$ & & $-0,293$ & ,878* & ,878* & $-0,098$ &,$- 891 *$ & $-0,293$ & $-0,683$ \\
\hline Test Angle & $\begin{array}{l}\text { Sig. (2- } \\
\text { tailed) }\end{array}$ & & 0,573 & 0,021 & 0,021 & 0,854 & 0,017 & 0,573 & 0,135 \\
\hline Initial & $\begin{array}{c}\text { Correlation } \\
\text { Coefficient }\end{array}$ & $-0,293$ & & $-0,143$ & $-0,143$ & $-0,429$ & 0,029 & 0,086 & 0,200 \\
\hline $\begin{array}{l}\text { Rotational } \\
\text { Freedom }\end{array}$ & $\begin{array}{l}\text { Sig. (2- } \\
\text { tailed) }\end{array}$ & 0,573 & & 0,787 & 0,787 & 0,397 & 0,957 & 0,872 & 0,704 \\
\hline Final & $\begin{array}{c}\text { Correlation } \\
\text { Coefficient }\end{array}$ & ,878* & $-0,143$ & & $1,000^{* *}$ & $-0,543$ &,$- 986^{* *}$ & $-0,429$ & $-0,314$ \\
\hline $\begin{array}{l}\text { Rotational } \\
\text { Freedom }\end{array}$ & $\begin{array}{l}\text { Sig. (2- } \\
\text { tailed) }\end{array}$ & 0,021 & 0,787 & & 0,000 & 0,266 & 0,000 & 0,397 & 0,544 \\
\hline Rotational & $\begin{array}{c}\text { Correlation } \\
\text { Coefficient }\end{array}$ & ,878* & $-0,143$ & $1,000^{* *}$ & & $-0,543$ &,$- 986^{* *}$ & $-0,429$ & $-0,314$ \\
\hline $\begin{array}{l}\text { Freedom } \\
\text { Increase }\end{array}$ & $\begin{array}{l}\text { Sig. (2- } \\
\text { tailed) }\end{array}$ & 0,021 & 0,787 & 0,000 & & 0,266 & 0,000 & 0,397 & 0,544 \\
\hline $\begin{array}{l}\text { Implant } \\
\text { Volume }\end{array}$ & $\begin{array}{c}\text { Correlation } \\
\text { Coefficient }\end{array}$ & $-0,098$ & $-0,429$ & $-0,543$ & $-0,543$ & & 0,522 & 0,257 & $-0,486$ \\
\hline $\begin{array}{l}\text { Loss } \\
\text { (mm3) }\end{array}$ & $\begin{array}{l}\text { Sig. (2- } \\
\text { tailed) }\end{array}$ & 0,854 & 0,397 & 0,266 & 0,266 & & 0,288 & 0,623 & 0,329 \\
\hline $\begin{array}{l}\text { Abutment } \\
\text { Volume }\end{array}$ & $\begin{array}{c}\text { Correlation } \\
\text { Coefficient }\end{array}$ &,$- 891^{*}$ & 0,029 &,$- 986^{* *}$ &,$- 986^{* *}$ & 0,522 & & 0,406 & 0,406 \\
\hline $\begin{array}{c}\text { Loss } \\
(\mathrm{mm} 3)\end{array}$ & $\begin{array}{l}\text { Sig. (2- } \\
\text { tailed) }\end{array}$ & 0,017 & 0,957 & 0,000 & 0,000 & 0,288 & & 0,425 & 0,425 \\
\hline Max & $\begin{array}{c}\text { Correlation } \\
\text { Coefficient }\end{array}$ & $-0,293$ & 0,086 & $-0,429$ & $-0,429$ & 0,257 & 0,406 & & $-0,086$ \\
\hline $\begin{array}{l}\text { Torque } \\
\text { Clockwise }\end{array}$ & $\begin{array}{l}\text { Sig. (2- } \\
\text { tailed) }\end{array}$ & 0,573 & 0,872 & 0,397 & 0,397 & 0,623 & 0,425 & & 0,872 \\
\hline $\begin{array}{c}\text { Max } \\
\text { Torque }\end{array}$ & $\begin{array}{c}\text { Correlation } \\
\text { Coefficient }\end{array}$ & $-0,683$ & 0,200 & $-0,314$ & $-0,314$ & $-0,486$ & 0,406 & $-0,086$ & \\
\hline $\begin{array}{l}\text { Counter } \\
\text { Clockwise }\end{array}$ & $\begin{array}{l}\begin{array}{l}\text { Sig. (2- } \\
\text { tailed) }\end{array} \\
\end{array}$ & 0,135 & 0,704 & 0,544 & 0,544 & 0,329 & 0,425 & 0,872 & \\
\hline
\end{tabular}

*. Correlation is significant at the 0.05 level (2-tailed).

**. Correlation is significant at the 0.01 level (2-tailed)

Table 5: Spearman's correlation analysis comparing Groups A and B.

From the SEM evaluation (Figure 1-5) it is possible to observe fracture lines on the titanium implant and wear of the titanium hexagons. In the control group both the implant and the abutment hexagon did not show evidence of wear but there was adhesive wear on the outside ring of both components. There was evidence of adhesive wear and abrasion in both components of group B (titanium abutment) in all areas. In Group C (Zirconia abutments) there was adhesive wear, with oxidation and abrasion on the implant surfaces. On the zirconia abutment there was little adhesive wear. In all groups there was a lot of debris particles released from the wear.

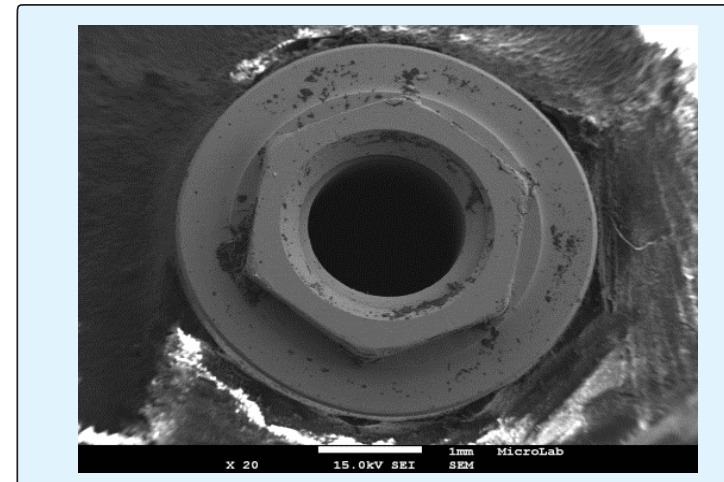

Figure 1: SEM of implant hexagon control group. 


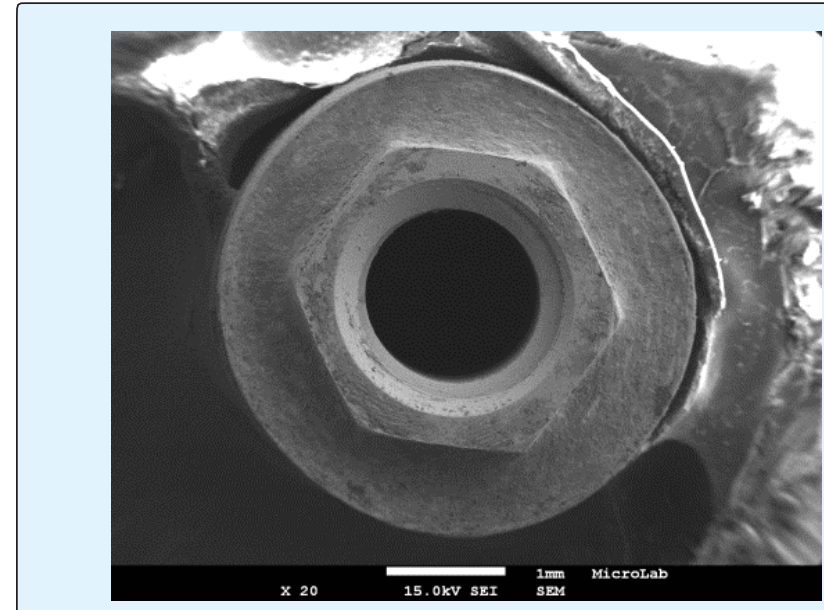

Figure 2: SEM of implant hexagon group A.

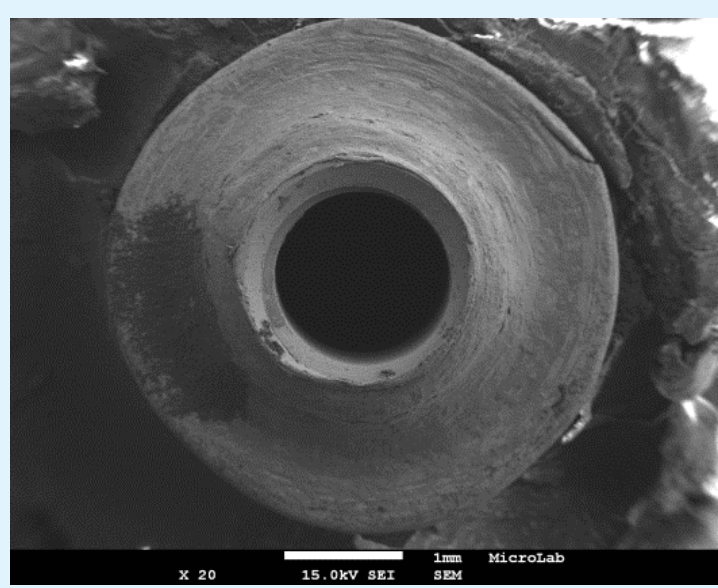

Figure 3: SEM of implant hexagon group C.

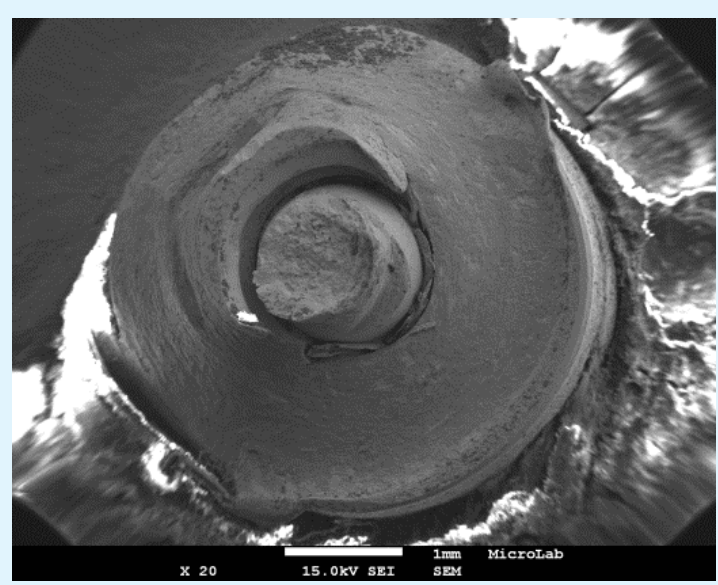

Figure 4: SEM of implant hexagon group D Titanium abutment.

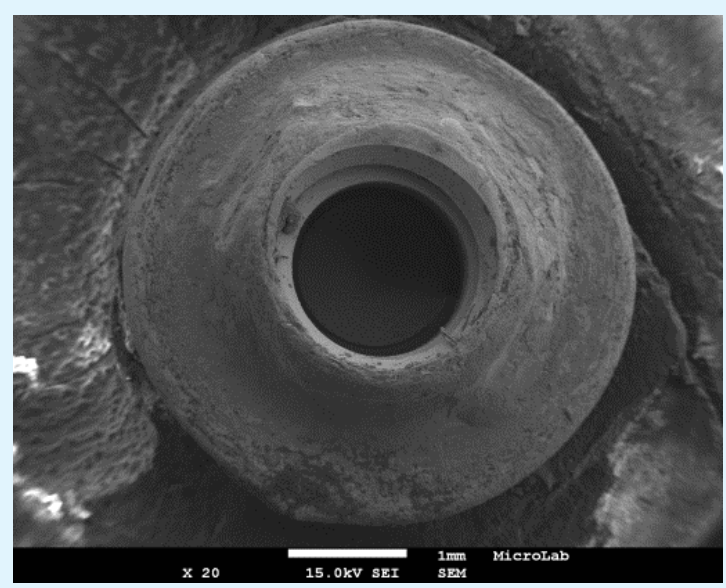

Figure 5: SEM of implant hexagon group D Zircnonia abutment.

\section{Discussion}

The fatigue test increased the average rotational freedom due to the wear of the hexagons of the implant. The abutment hexagon suffers minimal damage in the Zirconia abutments but not in the Titanium. Although no significant correlation can be made with the Spearman's analysis, there is a negative correlation between the rotational freedom and the wear of the titanium implant, i.e., as the rotational freedom increases the wear decreases. As the wear of the zirconia abutment is very small there is a small correlation but not significant with the torque registered by the machine. This can be attributed to the lower hardness of the titanium alloy. Commercially pure Titanium has a Vickers hardness of $200 \mathrm{HV}$ while the annealed Ti-6Al-4V is $340 \mathrm{HV}$ [13]. Zirconia has a Vickers hardness almost four times higher of $1300 \mathrm{HV}$ [14]. Also Titanium Mohs Hardness is 5.5 while is Zirconia 8. [15]. High-cycle fatigue limits for Ti $6 \mathrm{Al}-4 \mathrm{~V}$ are greatly influenced by both microstructure and surface conditions [16]. Even though Ti-6Al-4V has a fracture toughness several times higher than Zirconia at $75 \mathrm{MPa}^{1 / 2}$ the material is too soft for the Zirconia $[17,18]$. Zirconia only has a fracture toughness of $5 \mathrm{MPa}-$ $\mathrm{m}^{1 / 2}$ [19], studies that evaluate the rotational freedom of implants or abutments show different results due to differences in machining tolerances of the different implant systems [20]. All implants but the control had the angles of the connection abraded and the circular platform where the abutment rests worn. This is consistent with the observations of Yao, et al. [21], Dhingra [22] also made reference to a rounding of the hexagon when the abutment used was either titanium or zirconia. Zirconia abutments caused a higher wear. In both cases debris were found [22]. 


\section{Open Access Journal of Dental Sciences}

Like Yüzügüllü's [23] results, we found that the mating surfaces of the titanium abutment and the implant are separated and abraded. Although we found no fretting we did find breakage of the titanium implant external wall and adhesive wear. It is possible that $3^{\text {rd }}$ body wear was present but our findings are not conclusive. Contrary to Yüzügüllü, we found a lot of debris after testing and in the SEM images especially in the outer edges of the implant neck [23]. This is the only area that contacts the abutment, while it is being subjected to high loads, leading to wear of those surfaces and loss of material. This was an expected outcome from our previous work where with the same experimental setup we tested for Titanium and Zirconia abutments at $+/-3,3^{\circ}$ [24].

Williams and Williams state that all metals, noble or passivated, will suffer a slow removal of ions from the surface, largely because of local and temporal variations in microstructure and environment [25]. They also made reference to the rate may either increase or decrease with time and doesn't have to be continuous, but metal ions will be released into that environment upon prolonged implantation [25]. The titanium surface appears stable because there is an outer oxide layer. Nonetheless, the outer layer Titanium ions suffer a dissolution and precipitation in a continuous time. The corrosion and dissolution of metals can create an electrode reaction. The mechanism and spread of titanium ions through the body is not fully understood [26].

Implant corrosion, and the ion/particles release is one option to be considered as causing implant failure. There are studies that show a Titanium particle release associated with a successful implant osseointegration [2733]. Olmedo described the presence of macrophages loaded with Titanium particles in both peri-implant tissue of failed human dental implants and reactive lesions of the peri-implant mucosa an indication of corrosion [34]. Free Titanium ions can inhibit the growing of hydroxyapatite crystals and lead to local osteolysis with loss of implant stability [35].

Metal debris and ion release has been linked to the inhibition of cellular differentiation, cytotoxicity, phagocytosis of Titanium particles by macrophages and other cells, inflammation, and neoplasia [36-39]. Recent studies have shown that fretting and disruption of the oxidized surface of implants can cause increased corrosion current and generate open circuit potential in excess of $-500 \mathrm{mV}$ [40]. Abnormal electrical signals may affect the response and stability of the surrounding tissue, and contact corrosion can amplify other types of corrosion by the rupture of the passive film and exposing unoxidized Titanium [41]. These abnormal currents and coupled electrical potentials are directly related to the cyclic loads applied to the implant $[40,42]$. Application to dentistry and orthopedics, cyclic loading come from the forces exerted after each mastication cycle or each step, respectively. It is therefore reasonable to suggest that cells and tissues in individuals with implants are exposed to abnormal electrical signals over long periods of time [41].

It seems logical that whenever ceramic and metal meet, is the metal which erodes and wears. We also detected powder attached to the Zirconia abutments. This powder on the Zirconia abutments has been described by Klotz [43] and Dhingra [22] in 2011 and in 2013. In the study of Klotz [43] with 4 internal connection implants Astra (Astra Tech) observed a 8.3 times greater wear with Zirconia abutments than with Titanium abutments Klotz [43] and Dhingra [22] noted that the presence of residues in the interface of the implant and abutment as well as the screw head, presents a problem of third-body wear. Our SEM analysis cannot confirm this, we can only declare that it might have occurred during the test due to the amount of debris created. This powder is also observed in orthopedic joint prostheses, and has been shown to have biological consequences such as inflammation, pain, and limited movement [44-46]. Such effects have not been previously observed in dental implant systems because dentists are more inclined to think of a bacterial infection rather than a consequence of the wear of the implant connection.

Three new clinical studies published in 2014 on Titanium wear highlighting Titanium particles that were transferred to the pillars [47-49]. Tawse-Smith [48] describes the presence of Titanium in the surrounding gums, these might react as if it were a foreign body with histological evidence and SEM [48]. Wilson [49] describes the presence of Titanium and cement, speculating how the Titanium originated: due to wear or corrosion $[47,49]$ found Titanium residue in Zirconia abutments (Cercon FRIADENT $® ~ \circledR$ Abutment, Dentsply Friadent) and wear of the internal hexagon connection XiVE® S plus implants (Dentsply Friadent, Mannheim, Germany) [47]. We believe that the lack of articles is not due to the fact that there is no problem, but has it develops slowly over time, in the future there will be clinical problems in the literature. The loose screw in an implant prosthesis may lead to the wear of the hexagon on both components. The wear is sufficient to compromise the implant abutment connection beyond repair. When a patient presents a loose crown, the dentist, should inspect both the connection on the implant and abutment and to take 


\section{Open Access Journal of Dental Sciences}

preventive measures if necessary and to report this event to further research in this area.

\section{Acknowledgements}

The authors would like to thank MIS Implants Technologies Ltd, Bar Lev Industrial Park, Israel for supplying the materials. This work was supported by FCT, through IDMEC, under LAETA, project UID/EMS/50022/2013

\section{References}

1. Ma S, Fenton A (2015) Screw- versus cementretained implant prostheses: a systematic review of prosthodontic maintenance and complications. Int J Prosthodont 28(2): 127-145.

2. Sherif S, Susarla HK, Kapos T, Munoz D, Chang BM, et al. (2014) A systematic review of screw- versus cement-retained implant-supported fixed restorations. J Prosthodont 23(1): 1-9.

3. Berglundh T, Persson L, Klinge B (2002) A Systematic Review of the Incidence of Biological and Technical Complications in Implant Dentistry Reported in Prospective Longitudinal Studies of at Least 5 Years. J Clin Periodontol 3: 197-212.

4. Esposito M, Hirsch JM, Lekholm U, Thomsen $P$ (1998) Biological Factors Contributing to Failures of Osseointegrated Oral Implants. (II). Etiopathogenesis. European Journal of Oral Sciences 106(3): 721-764.

5. Goodacre CJ, Kan JY, Rungcharassaeng K (1999) Clinical Complications of Osseointegrated Implants. J Prosthet Dent 81(5): 537-552.

6. Cibirka RM, Nelson SK, Lang BR, Rueggeberg FA (2001) Examination of the Implant-Abutment Interface after Fatigue Testing. J Prosthet Dent 85(3): 268-275.

7. Cotes C, Arata A, Melo RM, Bottino MA, Machado JP, et al. (2014) Effects of Aging Procedures on the Topographic Surface, Structural Stability, and Mechanical Strength of a ZrO2-Based Dental Ceramic. Dent Mater 30(12): 396-404.

8. Canullo L, Paulo G C, Estevam A B (2013) Mechanical Testing of Thin-Walled Zirconia Abutments. J Appl Oral Sci 21(1): 20-24.
9. Gratton DG, Aquilino SA, Stanford CM (2001) Micromotion and Dynamic Fatigue Properties of the Dental Implant-Abutment Interface. J Prosthet Dent 85(1): 47-52.

10. Lee J, Kim YS, Kim CW, Han JS (2002) Wave Analysis of Implant Screw Loosening Using an Air Cylindrical Cyclic Loading Device. J Prosthet Dent 88(4): 402408.

11. Brodbeck U (2003) The ZiReal Post: A New Ceramic Implant Abutment. J Esthet Restor Dent 15(1): 1023.

12. Mathieu V, Vayron R, Richard G, Lambert G, Naili S, et al. (2014) Biomechanical Determinants of the Stability of Dental Implants: Influence of the BoneImplant Interface Properties. J Biomechanics 47(1): 3-13.

13. Da Rocha SS, Gelson LA, Guilherme EPH, Mauro Antonio De AN (2006) Vickers Hardness of Cast Commercially Pure Titanium and Ti-6Al-4V Alloy Submitted to Heat Treatments. Brazilian Dental Journal 17(2): 126-129.

14. Cadence nd Zirconia Ceramic http://cadenceinc.com/technology-designcenter/materials-coatings-information/zirconiaceramic/.

15. Reade (2016) Mohs' Hardness (Typical) of Abrasives.

16. Carpenter (2000) Titanium Alloy Ti 6Al-4V Technical Datasheet.

17. Salem JA, Lerch B, Thesken JC, Sutter J, Russell R (2008) Strength, Fatigue, and Fracture Toughness of Ti -6Al-4V Liner From a Composite Over- Wrapped Pressure Vessel. NASA Scientific and Technical Information.

18. Joseph RD (1997) The Materials Information Company. In: Joseph RD Metals Handbook, edited by America Society for Metals.

19. Marinis A, Aquilino SA, Lund PS, Gratton DG, Stanford CM, et al. (2013) Fracture Toughness of Yttria-Stabilized Zirconia Sintered in Conventional and Microwave Ovens. J Prosthet Dent 109(3): 165171.

20. Jansen VK, Conrads G, Richter EJ (1997) Microbial Leakage and Marginal Fit of the Implant-Abutment 


\section{Open Access Journal of Dental Sciences}

Interface. Int J Oral Maxillofac Implants 12(4): 527 540.

21. Yao KT, Kao HC, Cheng CK, Fang HW, Yip SW, et al. (2012) The Effect of Clockwise and Counterclockwise Twisting Moments on Abutment Screw Loosening. Clin Oral Implants Res 23(10): 1181-1186.

22. Dhingra A, Weiner S, Luke AC, Ricci JL (2013) Analysis of Dimensional Changes in the Screw and the Surface Topography at the Interface of a Titanium Screw and a Zirconia Abutment under Cyclic Loading: An in Vitro Study. Int J Oral Maxillofac Implants 28(3): 661-669.

23. Yüzügüllü B, Avci M (2008) The Implant-Abutment Interface of Alumina and Zirconia Abutments. Clin Implant Dent Relat Res 10(2): 113-121.

24. Reis J, Maurício P, Reis L, Fátima V (2015) Wear of the Implant Hexagon With Zirconia and Titatnium Abutments, Loose Screw. J Dent Res 94(A): 2266.

25. Williams DF, Williams RL (2004) Degradative Effects of the Biological Environment on Metals and Ceramics. In: Buddy DR, et al. (Eds.), Biomaterials Science: An Intoduction to Materials in Medicine London: Elsevier Academic Press. pp: 430-439.

26. Suito H, Iwawaki $Y$, Goto T, Tomotake $Y$, Ichikawa $T$ (2013) Oral Factors Affecting Titanium Elution and Corrosion: An in Vitro Study Using Simulated Body Fluid. PloS One 8(6): e66052.

27. Flatebø RS, Johannessen AC, Grønningsaeter AG, Bøe OE, Gjerdet NR, et al. (2006) Host Response to Titanium Dental Implant Placement Evaluated in a Human Oral Model. J Periodontol 77(7): 1201-1210.

28. Guindy JS, Schiel H, Schmidli F, Wirz J (2004) Corrosion at the Marginal Gap of Implant-Supported Suprastructures and Implant Failure. Int J Oral Maxillofac Implants 19(6): 826-831.

29. Olmedo DG, Duffó G, Cabrini RL, Guglielmotti MB (2008) Local Effect of Titanium Implant Corrosion: An Experimental Study in Rats. Int J Oral Maxillofac Surg 37(11): 1032-1038.

30. Olmedo DG, Paparella ML, Brandizzi D, Cabrini RL (2010) Reactive Lesions of Peri-Implant Mucosa Associated with Titanium Dental Implants: A Report of 2 Cases. Int J Oral Maxillofac Surg 39(5): 503-507.
31. Olmedo DG, Paparella ML, Spielberg M, Brandizzi D, Guglielmotti MB, et al. (2012) Oral Mucosa Tissue Response to Titanium Cover Screws. J Periodontol 83(8): 973-980.

32. Tagger Green N, Machtei EE, Horwitz J, Peled M (2002) Fracture of Dental Implants: Literature Review and Report of a Case. Implant Dent 11(2): 137-143.

33. Frisken KW, Dandie GW, Lugowski S, Jordan G (2002) A Study of Titanium Release into Body Organs Following the Insertion of Single Threaded Screw Implants into the Mandibles of Sheep. Aust Dent J 47(3): 214-217.

34. Olmedo D, Fernández MM, Guglielmotti MB, Cabrini RL (2003) Macrophages Related to Dental Implant Failure. Implant Dent 12(1): 75-80.

35. Chaturvedi TP (2009) An Overview of the Corrosion Aspect of Dental Implants (Titanium and Its Alloys)." Indian J Dent Res 20(1): 91-98.

36. Doran A, Law FC, Allen MJ, Rushton N (1998) Neoplastic Transformation of Cells by Soluble but Not Particulate Forms of Metals Used in Orthopaedic Implants. Biomaterials 19(7-9): 751759.

37. Lohmann CH, David DD, Koster G, Casasola D, Buchhorn GH, et al. (2002) Ceramic and PMMA Particles Differentially Affect Osteoblast Phenotype. Biomaterials 23(8): 1855-1863.

38. Rahal MD, Delorme D, Brånemark PI, Osmond DG (2000) Myelointegration of Titanium Implants: B Lymphopoiesis and Hemopoietic Cell Proliferation in Mouse Bone Marrow Exposed to Titanium Implants. Int J Oral Maxillofac Implants 15(2): 175184.

39. Sun ZL, Wataha JC, Hanks CT (1997) Effects of Metal Ions on Osteoblast-like Cell Metabolism and Differentiation. J Biomed Mater Res 34(1): 29-37.

40. Gilbert JL, Mehta M, Pinder B (2009) Fretting Crevice Corrosion of Stainless Steel Stem-CoCr Femoral Head Connections: Comparisons of Materials, Initial Moisture, and Offset Length. J Biomed Mater Res B Appl Biomater 88(1): 162-173.

41. Gittens RA, Olivares-Navarrete R, Tannenbaum R, Boyan BD, Schwartz Z (2011) Electrical Implications 


\section{Open Access Journal of Dental Sciences}

of Corrosion for Osseointegration of Titanium Implants. J Dent Res 90(12): 1389-1397.

42. Goldberg JR, Gilbert JL (1997) Electrochemical Response of CoCrMo to High-Speed Fracture of Its Metal Oxide Using an Electrochemical Scratch Test Method. J Biomed Mater Res 37(3): 421-431.

43. Klotz MW, Taylor TD, Goldberg AJ (2011) Wear at the Titanium-Zirconia Implant-Abutment Interface: A Pilot Study. Int J Oral Maxillofac Implants 26(5): 970-975.

44. Bonnaig NS, Freiberg RA, Freiberg AA (2011) Total Hip Arthroplasty with Ceramic-on-Ceramic Bearing Failure from Third-Body Wear. Orthopedics 34(2): 132.

45. Davidson JA, Poggie RA, Mishra AK (1994) Abrasive Wear of Ceramic, Metal, and UHMWPE Bearing Surfaces from Third-Body Bone, PMMA Bone Cement, and Titanium Debris. Bio-Med Mater Eng 4(3): 213-229.
46. Ingham E, Fisher J (2000) Biological Reactions to Wear Debris in Total Joint Replacement. Proc Inst Mech Eng H 214(1): 21-37.

47. Nothdurft FP, Nonhoff J, Pospiech PR (2014) PreFabricated Zirconium Dioxide Implant Abutments for Single-Tooth Replacement in the Posterior Region: Success and Failure after 3 Years of Function. Acta Odontologica Scand 72(5): 392-400.

48. Tawse-Smith A, Momen AA, Jonathan L, Liz G, Alison MR (2014) Peri-Implant Bone Loss and Its Uncommon Causes: A Case Report. Clinical Advances in Periodontics 5(4): 242-247.

49. Wilson TG, Valderrama P, Burbano M, Blansett J, Levine R, et al. (2014) Foreign Bodies Associated With Peri-Implantitis-Human Biopsies. Periodontol 86(1): 9-15. 